Бабій, Ірина. «Типологія та функції односкладних речень у романі „Марія” Уласа Самчука». Лінгвостилістичні студіï, вип. 13, 2020, с. 7-15.

Babii, Iryna. "One-member sentences in the novel "Maria" by Ulas Samchuk: typology and functions". Linguostylistic Studies, iss. 13, 2020, pp. 7-15.

УДК 811.161.3'373:821.161.3.09-1

https://doi.org/10.29038/2413-0923-2020-13-7-15

\title{
ТИПОЛОГІЯ ТА ФУНКЦІЇ ОДНОСКЛАДНИХ РЕЧЕНЬ У РОМАНІ «МАРІЯ» УЛАСА САМЧУКА
}

\author{
Ірина Бабій \\ Тернопільський національний педагогічний університет імені Володимира Гнатюка, \\ Тернопіль, Україна
}

Стаття присвячена розгляду односкладних речень у романі Уласа Самчука «Марія». У сучасній синтаксичній теорії проблема вивчення односкладних речень $\epsilon$ актуальною. У статті охарактеризовано односкладні речення 3 формальнограматичного і семантичного погляду, описано основні типи цих речень. Простежено своєрідність синтаксичної будови та функціонування односкладних речень у прозовій мові Уласа Самчука. У результаті розгляду семантико-синтаксичної організації художньої оповіді Уласа Самчука виявлено, що письменник часто вживає односкладні конструкції, наділяючи їх різноманітною естетичною вагою.

Ключові слова: типи односкладних речень, означено-особові речення, неозначено-особові речення, узагальнено-особові речення, безособові речення.

\section{ONE-MEMBER SENTENCES IN THE NOVEL «MARIA» BY ULAS SAMCHUK: TYPOLOGY AND FUNCTIONS}

\section{Iryna Babii}

Ternopil Volodymyr Hnatiuk National Pedagogical University, Ternopil, Ukraine

The article elucidates the stylistic features of one-member sentences in the novel Maria by Ulas Samchuk. In modern theoretical studies on syntax, the issue of one-member sentences is still hotly debated and topical. The article characterizes one-member sentences from formal grammatical and semantic standpoints, describes the main types of these sentences. In the focus of this study is the originality of syntactic structure and functioning of one-member sentences in Ulas Samchuk's prose. The in-depth analysis of the semantic-syntactic organization of the novel Maria by Ulas Samchuk has revealed that the writer often uses onemember sentences, giving them a variety of aesthetic value. The most frequently used are definite-personal, indefinite-personal, impersonal, and nominative sentences. Using these one-word sentences, the author creates landscape sketches that serve as the background on which the events unfold. Ulas Samchuk fills his story with emotions and psychology. It is revealed that one-member sentences used in monologues and reflections of characters often help to reproduce their psychological state, to convey an assessment of the depicted events. U.Samchuk most often uses this type of sentences in depicting landscapes, in dialogues and

(c) Бабій І., Волинський національний університет імені Лесі Українки, 2020.

Це стаття відкритого доступу на умовах СC BY-NC 4.0 
monologues. Using these constructions, the author enriches the arsenal of visual and expressive means of artistic narration.

Key words: types of one-member sentences, definite-personal sentences, indefinitepersonal sentences, generalized personal sentences, impersonal sentences.

Вступ. Творчість Уласа Самчука - самобутнє явище в українській літературі XX ст. Несправедлива доля спіткала цього визначного й талановитого письменника та його творчість (забуття, еміграція, заборони, нездійснена мрія повернутися на Батьківщину тощо). Тривалий час художня спадщина Уласа Самчука залишалася невідомою для українського народу. 3 винятковою силою і майстерністю письменник описав життя та передав глибоку душу українців. На долю українського народу випало немало горя, страждань і трагедій, які, власне, й відображує автор у своїх творах. Письменник переживав за рідний народ, розумів і водночас підтримував своїх героїв, простих українських селян, в намаганні бути щасливими. 3 одного боку, автор зобразив їх важке життя, злигодні й щоденні турботи, біль і страждання, відтворив національну трагедію, «жах голодної смерті», а з іншого, - віру в краще життя, кохання, радощі материнства та надзвичайну любов до своєї землі. «У романах, особливо у «Марії», Самчук підходить до відображення життя з мірою українського вітаїзму - утвердження торжества життя в його найрізноманітніших проявах, навіть тоді, коли воно конвульсивно вибивається з небуття чи повисає над прірвою» (Гроно 205).

Тонкий психологізм, глибоке проникнення в проблему, майстерність художнього зображення Уласа Самчука сьогодні викликають науковий інтерес і літературознавців, і мовознавців. Наша розвідка присвячена аналізу односкладних речень (далі ОР). Ці конструкції характеризуються семантичною розгалуженістю та естетичною вагомістю в художній мові, часто вживаються в описах, монологах, діалогах тощо.

У сучасному мовознавстві питання вивчення односкладних речень і сьогодні залишається дискусійним та актуальним. Односкладними називають «речення 3 одним наявним головним членом, що не потребують поповнення другим головним членом» (Шульжук 113). Базовими в галузі синтаксису (зокрема, й щодо вивчення односкладних конструкцій) є праці С. Бевзенка, Л. Булаховського, I. Вихованця, Н. Гуйванюк, П. Дудика, А. Загнітка, М. Кобилянської, I. Слинько, Л. Прокопчук, Р. Христіанінової, К. Шульжука та ін. Однак, сьогодні в сучасній синтаксичній теорії наявні дискусії, що стосуються аналізу граматичної природи односкладних конструкцій, розгляду головного члена, класифікації односкладних речень тощо. В останні десятиріччя з'явилися праці, присвячені розгляду особливостей уживання ОР художньому мовленні.

Велику кількість односкладних конструкцій ужито у творах Уласа Самчука. Оскільки в сучасній лінгвістиці поки що відсутні праці, 
присвячені розгляду ОР у творах письменника, наше дослідження $\epsilon$ актуальним. Предметом аналізу будуть односкладні речення, виявлені в романі «Марія».

Мета праці - здійснити аналіз семантико-граматичної природи односкладних речень та їх функціонування в романі «Марія» Уласа Самчука.

Для реалізації зазначеної мети необхідно розв'язати такі завдання: а) застосувавши сучасну класифікацію односкладних речень, охарактеризувати типологію ОР, виявлених у романі «Марія»; б) описати семантикограматичну природу головного члена речень; в) простежити особливості вживання ОР у творі.

Матеріалом для дослідження слугував роман-хроніка «Марія» (1934р.) Уласа Самчука, в якому на прикладі однієї української родини відтворено життя всього народу у першій половині XX століття, описано традиції та звичаї українців, їх щиру і доброзичливу душу. Письменникові «вдалося у межах «хроніки одного життя» показати широке коло проблем, мотивів, колізій (життя і смерті, сирітства, кохання, шлюбу, батьків і дітей, віри в Бога й атеїзму, тоталітаризму, голоду тощо)» (Історія 495). Роман «Марія»перший твір, в якому описано голод 1933-34 р. в Україні. Головною героїнею роману є українська жінка-мати, жінка-страдниця Марія. Твір «витриманий у високому стилі художньої агіографії, що надає образу Марії вищого, надпобутового сенсу, наближуючи їі до біблійних героїнь і водночас підносячи цей образ до рівня символу України» (Гроно 205).

Методи дослідження. У роботі використано метод контекстного аналізу для з'ясування семантико-граматичної природи головного члена односкладних речень, описовий метод - для представлення різновидів цих речень, а також метод лінгвостилістичного спостереження - для встановлення особливостей їх функціонування в межах художнього тексту і вияву індивідуальних ознак використання.

Виклад основного матеріалу й обгрунтування результатів дослідження. У сучасному синтаксисі виділяють кілька різновидів ОР залежно від семантики та форми вираження головного члена, а саме: означено-особові, неозначено-особові, узагальнено-особові, безособові, інфінітивні, номінативні, вокативні, генітивні. Всі різновиди поділяють на дві групи: дієслівні й іменні.

Поширеним у мові різновидом OP є означено-особові, які найлегше можна визначити, оскільки «вони виразно спеціалізовані та індивідуалізовані, бо вказують на означену особу» (Дудик 134-135). Означено-особові речення - «різновид односкладних простих речень, у яких виконувач дії мислиться означено, а головний член виражений дієсловом у формі 1-ї або 2-ї особи однини чи множини теперішнього або майбутнього часу дійсного способу чи наказового способу» (Дудик 134). Найчастіше ці речення мовці вживають у діалогах, монологах, роздумах героїв. 
У романі «Марія» означено-особові речення становлять численну групу. Головний член у таких реченнях найчастіше виражений:

1) дієсловом 1 особи однини та множини дійсного способу, наприклад: «- Переб'ю ребра і другу ногу вирву» (Самчук 27); “ - Побачу. Може, зайду» (Самчук 27); «Так мало пам'ятаю їх, але тепер бачу і пізнаю їх виразно» (Самчук 41); «- E-е, Маріє... Гублю віру... У все гублю віру... Перестаю у землю вірити» (Самчук 109); «А там побачимо» (Самчук 114);

2) дієсловом 2 особи однини і множини дійсного способу, наприклад: «Ось досіємо - й тоді на вечірню» (Самчук 17); «Отак йдеш полями. Ті самі вони... і не ті» (Самчук 109);

3) дієсловом наказового способу, наприклад: «Не вводь у гріх сироти», говорив Романові Мартин» (Самчук 14); «- Кажи, оповідай!.. Мовчи, Палажко. Не стій, дівчино, й не виглядай» (Самчук 20); «- Гнате!.. Ти!.. Не муч мене! Слухай, прошу тебе, не ходи, не купуй!» (Самчук 22); «- Поглянь на Божий світ. Поглянь на наш сад, наше поле... Подивися, які он дерева... А пригадай, Маріє...» (Самчук 109).

Означено-особові речення у романі виражають емоційний стан персонажів, сприяють дієвості, руху висловлення.

Виконавець дії в неозначено-особових реченнях - присутній, але не названий; можна тільки здогадуватися про кого йдеться, хто виконує названу дію. Особи «сприймаються неозначено, не індивідуально» (Дудик 137). У виявлених у романі «Марія» неозначено-особових ОР головний член речення виражений:

1) дієсловом 3-ї особи множини теперішнього часу, наприклад: «Йдуть рівно, поволі... Ідуть, ідуть, ідуть» (Самчук 19); «Радять, метушаться» (Самчук 32); «Подають страви» (Самчук 34);

2) дієсловом минулого часу дійсного способу у множині, наприклад: «Написали бозна про якого мурина» (Самчук 14); «Поорали, посіяли, зняли яблука й сливи, викопали буряки, бараболі, порубали капусти. Корнія забрали у матроси» (Самчук 20); «У молодих знов зустрічали повінчаних 3 образами та хлібом. Знов вели до хати, садовили за стіл, їли та пили. Після вели молоду до комори, вдягали «тура», уводили до хати, дурили молодого. Уводили замість Марії накриту рядном стару бабу. Приводили, ставили перед молодим і співали» (Самчук 36).

У романі «Марія» неозначено-особові речення найчастіше вжиті в діалогах. У таких реченнях основна увага спрямована на події, факті, на дії, які виконує герой.

Серед односкладних речень поширеним $\epsilon$ різновид узагальненоособових речень, названа дія в яких стосується всіх і кожного. У таких реченнях дія «сприймається узагальнено, як така, що характерна за певних умов для будь-кого» (Дудик 141). У виявлених реченнях головний член найчастіше виражений дієсловом 2 особи однини і множини, наприклад: «Видно, проти долі не підеш...» (Самчук 35); «Бий тебе сила Божа!» (Самчук 105). Рідше - дієсловом 1 особи теперішнього або 
майбутнього часу, формою чоловічого або жіночого роду минулого часу, наприклад: «Віддамо тіло снові» (Самчук 130); «А то вбив собі в голову» (Самчук 73).

Найуживанішими в мові $\epsilon$ безособові речення, в яких «головний член означає стихійну дію чи стан природи або таку дію чи стан особи, які настають незалежно від ії волі» (Дудик 145). Безособові речення, виявлені в романі «Марія», з огляду на семантику можна об'єднати у групи, які виражають:

1) стан природи, наприклад: «Надворі вже вечоріло!» (Дудик 114); «Темно. Темно на землі» (Самчук 66); «Весняно і тихо. Пахне земля міцними випарами» (Самчук 73); «Темно і зоряно» (Самчук 75); «Стемніло» (Самчук 50);

2) дію невизначеного діяча, стихійної сили тощо, наприклад: «Як-неяк чоловік є. Створено його по образу і подобію Божію» (Самчук 103);

3) фізичний і психічний стан людини, наприклад: «Марія хихотить. Приємно» (Самчук 19); «Страшно за твою таку красу» (Самчук 22); «- Тошненько мені та нудненько мені! Що то буде з тією жінкою?» (Самчук 44); «Прикро і боляче. Пішла все-таки» (Самчук 57); «Ні. Весело їй» (Самчук 58); «Душно» (Самчук 30);

4) стан, зумовлений відсутністю чогось або когось, наприклад: «Не має сили» (Самчук 22); «Тихо. Нема відзвуку» (Самчук 25); «Нема тобі, Маріє, звороту» (Самчук 45); «Нема вже осини, нема запахів горілого бараболиння, нема шелесту кукурудзяного листу і розцілованих барвистих яблунь» (Самчук 124);

5) дію неусвідомленої сили, наприклад: « Для збору бур'янів кинуто цілий народ, військо, пресу, письменників і вчених» (Самчук 125); «3 далеких піль віяло запахом чорнозему» (Самчук 133);

6) для передачі різних модальних значень (можливості, неминучості тощо), наприклад: «Не можна так на галай-балай» (Самчук 17); «Треба ж вченим наперед віддати шану» (Самчук 29); «Треба гасати, грати у свинки, колдовку» (Самчук 12); «Їй же треба ще одно відро води» (Самчук 15).

У виявлених безособових реченнях головний член виражений:

1) безособовим дієсловом, наприклад: «Стемніло» (Самчук 50); «Вечоріло. Чекав на Марію» (Самчук 56); «Смеркає» (Самчук 123);

2) безособовим дієсловом на -ся (-сь), наприклад: «Хочеться пити й n'яніти» (Самчук 8); «Робилося шкода затраченого дівоцтва. Хотілося мстити комусь» (Самчук 46); «Не думалось і не могло думатися, що і цьому буде край» (Самчук 52); «Спати в таку ніч не хочеться» (Самчук 65); «А тепер? Ходилося по лісах, запустах, збиралося дичечки, тицялося рівними рядочками, щодня заглядалося до них» (Самчук 110);

3) особовим дієсловом у значенні безособового, наприклад: «3 далеких піль віяло запахом чорнозему» (Самчук 133);

4) безособовим дієсловом на -но, -то, наприклад: «Батька зовсім не видно» (Самчук 10); "Початок зроблено» (Самчук 60); «Перед святами напечено гори повних паляниць, книшів» (Самчук 64); «У передньому куті 
стіл, на нім насипано зерно, сіно і застелено білим доморобним настільником» (Самчук 65);

5) предикативним прислівником на -o, -e, які можуть уживатися 3 допоміжним дієсловом стало, було, робиться і под., наприклад: «Йому було скрізь тяжко. Може, там буде легше...» (Самчук 10); «Прикро й боляче...» (Самчук 12); «Надто тут спокійно, надто радісно» (Самчук 18); «- Ніяково. У мене ж діти, господарство» (Самчук 73); «Легко, радісно» (Самчук 86);

6) предикативно-безособовими словами треба, слід, можна, необхідно, доцільно і под. стан разом 3 інфінітивом або без нього, наприклад: «Тепер вже й потанцювати можна» (Самчук 26); «Треба на шлюб благословити» (Самчук 32); «Нелегка це річ. Треба гроша, а де його взяти. Треба сили, треба людей» (Самчук 69); «Ех, Маріє... Хіба можна вірити далі і хіба потрібно жити?» (Самчук 110);

7)заперечним словом нема (немає), наприклад: «Нема. Не може бути» (Самчук 46); «Шлюбу нема, родин нема, мерлин нема» (Самчук 103).

Серед односкладних речень у сучасному синтаксисі виділяють групу інфінітивних речень, «які мають і семантично незалежний від інших членів речення інфінітив у ролі головного члена» (Дудик 156). Тривалий час інфінітивні речення розглядали серед безособових. В інфінітивних односкладних реченнях, виявлених у романі «Марія», виражається:

- категоричний наказ, спонукання, заклик до дії, наприклад: «- Не вчити, а бити» (Самчук 107); «Не личить бути жінці вищою від чоловіка» (Самчук 26);

- запитання, сумнів, вагання, нерішучості, виражені у формі запитань, наприклад: «Відкинути? А як відкинеш, коли вона шовкова i коли так приємно на неї дивитися» (Самчук 22);

- неминучість, можливість, неможливість у заперечних інфінітивних реченнях тощо: «Не вгамувати його, не втримати» (Самчук 28);

- порада, бажана дія в інфінітивних реченнях із часткою би (б), наприклад: «Ах, коли б про своє, про власне розповісти. Коли б розказати думи свої» (Самчук 14); «Боже, Боже!.. Коли б нам скоріше доробитися чого!..» (Самчук 63).

За допомогою безособових речень автор висловлює різні модальні значення, емоції, почуття героїв.

Численну групу становлять також номінативні речення. На відміну від охарактеризованих дієслівних речень, головний член в цих ОР виражений не дієсловом, а іменником. Номінативні речення - різновид ОР, «якими стверджується буття предмета, явища або особи і які мають головний член речення, виражений лексемою у називному відмінку або сполученням слів із прямим відмінком у центрі» (Дудик 161). Як правило, 3 огляду на семантику науковці виділяють такі семантичні групи:

1) буттєві (екзистенціальні) речення, в яких охарактеризовано:

- предмети, що називають предмети, явища природи, географічні об’єкти, наприклад: «Зима, морози і сніги» (Самчук 24); «Тиша. Приморозь» 
(Самчук 78); «Новий рік. Водохрещі» (Самчук 26); «Ніч і мороз. Тиша» (Самчук 28); «Золота пахуча осінь» (Самчук 40); «Тихий морозний вечір» (Самчук 64);

- психічний стан людей, наприклад: «Жалібні співи, кадильний дим, ридання Марії і жінок» (Самчук 43); «Порвані і загнані мужики» (Самчук 118);

2) вказівні речення, що вказують на особу, предмет. У них поряд з іменником у називному відмінку вжито вказівні частки ось, он, от, онде, осьде, наприклад: «Ось і перелаз, гайок» (Самчук 19); «Це вогонь $і$ вода» (Самчук 67); «Ні, це перший півень» (Самчук 75); «Це революція» (Самчук 96);

3) оцінні номінативні речення, що містять емоційну оцінку, наприклад: «Золота дівка. Що не похопить - горить у руках» (Самчук 32); «Тяжкі зернисті снопи. Край золотий, край праці і хліба» (Самчук 63); «Але у Марії на душі суга. Тяжка і чорна суга» (Самчук 74).

Номінативні речення виконують називну функцію. За допомогою таких конструкцій автор характеризує природу, пору року, обставини, в яких відбуваються дії, а також емоційний стан персонажів. Письменник часто вживає номінативні речення на початку розділів роману, абзаців.

Останнім часом у лінгвістиці серед односкладних речень виділяють вокативні речення, які ще називають реченнями-звертаннями. Ці речення «нерозчленовано виражають думку, почуття, волевиявлення i завдяки різному інтонаційному оформленню можуть передавати заклик, застереження, спонукання, докір, обурення тощо» (Бевзенко, Литвин, і Семеренко 104). У романі «Марія» виявлені вокативні речення:

1) виражають звернення до адресата мовлення, щоб привернути його уяву, наприклад: «- Мамо! Де наш тато?.. Куди його віднесли? Тату!.. Tату!.. - Ах, дитино, дитино!» (Самчук 10); «- Тіточко, люба! Але ж я так

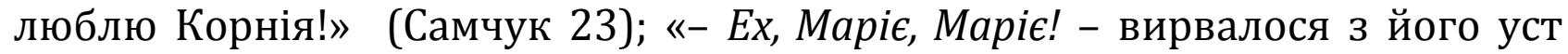
глибоке й болюче» (Самчук 25);

2) передають емоційні реакції мовців, наприклад: «Ex, Mapiє! Ex, mu, ти!.. Не все Марія співає» (Самчук 13); «- Любий мій! Любий мій! - палко вишіптує Марія» (Самчук 20); «-О мій ти цвяшечку! О мій крикунчику!.. Моє янголятко любе!.. - щебетала Марія» (Самчук 38); «- Ти-и! Чорте! Сатано! вереснув Лаврін» (Самчук 114);

3) містять спонукання, заборону, застереження тощо, наприклад: «- $A x$, Боже, Боже! - виривається тяжке зітхання» (Самчук 34); «- $О$ Боже, o Боже!.. Що ти говориш?.. Гнате, отямся!..» (Самчук 81); «Maтері! Чого ви плачете, матері? Шкода вам ваших синів?» (Самчук 89).

у романі «Марія» вокативні речення вжиті в діалогах, емоційно забарвленому мовленні. За допомогою таких речень письменник виражає емоційний стан героїв, часто ці речення передають стривоженість, розпач, страх людини.

До номінативних близькі генітивні речення, які зовсім недавно почали виділяти лінгвісти. До таких ОР відносять речення, в яких 
головний член виражений іменником або займенником у родовому відмінку, що «передає не тільки значення наявності, існування предмета, а й вказує на його кількісну ознаку» (Дудик 104). Як правило, ці речення поділяють на стверджувальні і заперечні. У романі «Марія» виявлено кілька стверджувальних генітивних речень, а саме: «Реготу, захоплення. Господи!» (Самчук 27); «Книг у них» (Самчук 13).

Розглянувши семантико-синтаксичну організацію художньої оповіді Уласа Самчука, зазначимо, що письменник часто вживає односкладні конструкції, наділяючи їх різноманітною естетичною вагою. Найбільш уживані означено-особові, неозначено-особові, безособові і номінативні речення. За допомогою них автор створює пейзажні замальовки, котрі виступають тлом, на якому розгортаються події. Улас Самчук наснажує свою оповідь емоційністю та психологічністю. Односкладні речення вжиті в монологах героїв, в їх роздумах, відтворюють психологічний стан персонажів, передають оцінку зображуваним подіям.

Висновки та перспективи дослідження. Отже, односкладні речення, виявлені в романі «Марія» Уласа Самчука, становлять семантично та функціонально розгалужену систему. Серед виявлених ОР найчисельнішими $\epsilon$ групи означено-особових, неозначено-особових, безособових та номінативних речень. Письменник найчастіше вживає ОР в пейзажах, діалогах, монологах. За допомогою таких конструкцій автор збагачує арсенал зображально-виражальних засобів художньої оповіді.

Зазначимо, що в лінгвістиці поки що грунтовно і глибоко не проаналізовано семантико-синтаксичну організацію художньої оповіді Уласа Самчука, тому вивчення синтаксичних конструкцій є актуальним і потребує глибокого мовознавчого аналізу. Творчість Уласа Самчука багатий матеріал для дослідження.

\section{Список використаної літератури}

Бевзенко, Степан, Литвин, Любов, і Семеренко, Ганна. Сучасна українська мова. Синтаксис. Київ: Вища школа, 2005.

Гроно нездоланих співців: Літературні портрети українських письменників ХХ ст., упоряд. В. І. Кузьменко. Київ: Український письменник, 1997.

Дудик, Петро, і Прокопчук, Людмила. Синтаксис української мови. Київ: ВЦ «Академія», 2010.

Історія української літератури XX - початку XXI cm., за ред. В. І. Кузьменка. У 3 т. Т. 1. Київ: Академвидав, 2013.

Самчук, Улас. Марія; Куди тече та річка. Київ: Наукова думка, 2001.

Шульжук, Каленик. Синтаксис української мови. Київ: ВЦ «Академія», 2004.

\section{References}

Bevzenko, Stepan, Lytvyn, Liubov, and Semerenko, Hanna. Suchasna ukrainska mova. Syntaksys. Kyiv: Vyshcha shkola, 2005.

Hrono nezdolanykh spivtsiv: Literaturni portrety ukrainskykh pysmennykiv XX st., edited by

V. I. Kuzmenko. Kyiv: Ukrainskyi pysmennyk, 1997. 
Dudyk, Petro, and Prokopchuk, Liudmyla. Syntaksys ukrainskoi movy. Kyiv: VTs "Akademiia", 2010.

Istoriia ukrainskoi literatury XX - pochatku XXI st., edited by V. I. Kuzmenka. 3 vols. Vol. 1. Kyiv: Akademvydav, 2013.

Samchuk, Ulas. Mariia; Kudy teche ta richka. Kyiv: Naukova dumka, 2001.

Shulzhuk, Kalenyk. Syntaksys ukrainskoi movy. Kyiv: VTs “Akademiia”, 2004.

Стаття надійшла до редколегії 24.09.2020 